\title{
Assessment of the Quality of Groundwater for Drinking Purpose in Rajanpur Tehsil, Pakistan
}

\author{
Zafar Ali Siyal ${ }^{1,}{ }^{*}$, Adeel Ahmed ${ }^{1}$, Kamran Ahmed Samo ${ }^{2}$, Imran Ahmed Samo ${ }^{1}$, Erum Pathan ${ }^{3}$ \\ ${ }^{1}$ Department of Energy \& Environment Engineering, QUEST, Nawabsah, Pakistan. \\ ${ }^{2}$ Department of Electrical Engineering, QUEST Campus Larkana, Pakistan. \\ ${ }^{3}$ Department of Electronic Engineering, QUEST, Nawabshah, Pakistan. \\ ${ }^{*}$ Corresponding author: zafarsiyal@quest.edu.pk
}

\section{Abstract}

\begin{abstract}
In this study, the quality of groundwater used for drinking purposes at Rajanpur Tehsil Pakistan is investigated. Water contamination causes several health problems to human being and the severity of problems mainly depends upon the level of pollutants present in water. Physical, chemical, and biological parameters of groundwater for twelve locations are analyzed using standard procedures. The obtained results are compared with the standards set by WHO. Most of the chemical parameters are found within the WHO standards except Arsenic, Calcium, and Sulfate at various locations. The Arsenic is found beyond WHO standards at nine locations with an increased percentage of $400 \%$ at three locations namely village Mehre Wala, Sehnwal, Near Basti Bhayan, and is also found beyond the permissible limit, i.e., upto $150 \%$ at six locations Sikhaniwala, Kot Mithan, Basti Nazru, Basti Asni, Jalal Pur, and Qutab Pul. Only three locations show satisfactory results, namely village shikarpur, village Murghai and Basti Lakha. The percentage of calcium at five locations such as Murghai, Basti Nazru, Basti Asni, Basti Lakha, and Chak Jalal Pur (Pull Pathan) is found to be $44 \%, 12 \%, 17.33 \%, 76 \%$, and $49.33 \%$, which is much higher than the WHO standards. Meanwhile, the Sulphate is also found to be beyond WHO standards at four locations, i.e. $30.8 \%$ for Mehrewala, 37.6\% for Murghai, 34.8\% for Basti Lakha and 34\% for Chak Jalal Pur (Pull Pathan). Biological contamination including total coliform and fecal coliform are found to be beyond the limit at Sehanwala, Rangpur, Shikarpur, and Basti Nazru locations. The higher percentage of Arsenic, calcium, and sulfate in water indicate that the groundwater is not suitable for drinking purpose. Sustainable water treatment is highly recommended for drinking water at the identified contaminated location.
\end{abstract}

Keywords—underground water, Arsenic, calcium, sulfate

\section{Introduction}

$\mathrm{P}$ URE, clean, and germ-free water is essential for human health. The availability of fresh clean water is declining rapidly due to population growth and human activities. Deteriorated quality of water is accountable for the death of around 5 million children in developing countries [1]. It is reported that $30 \%$ of diseases are identified due to worse water quality consumption in Pakistan including diarrhea in children which is a major water borne disease [2]. Treatment of drinking water is essential to eliminate various diseasecausing toxic substances, odor-producing agents, and to make the water suitable for drinking and other

ISSN: 2523-0379 (Online), ISSN: 1605-8607 (Print)

DOI: QRJ.1802.08

This is an open access article published by Quaid-e-Awam University of Engineering Science \& Technology, Nawabshah, Pakistan under CC BY 4.0 International License. domestic applications. Human welfare in modern life is linked with the quality of water consumed in everyday life. According to different health organization's standards, groundwater in several parts of Pakistan does not meet the quality standards for human consumption [3]. The groundwater quality depends on chemical, physical and bacterial characteristics, and thus determines the usefulness of water supply for the community [4].

The higher level of water pollution in rivers and groundwater results in biodiversity disturbance, water-borne diseases and reduced agricultural production. Not only water pollution but also the mismanagement of resources has sturdy socio-economic consequences on health and food security [5]. According to the report of State Bank of Pakistan, environmental health-related risks impose major health 
problems. Polluted water due to the presence of various organic, toxic elements, nitrates and nitrites can cause various health problems such as malfunctions of the human body, chronic diseases, and cancer [6]. Developing countries like Pakistan are facing water pollution problems due to the increase in population, industrialization, improper solid waste management and affluent discharge in canals and other water sources. The fast urbanization, deforestation, and land degradation have resulted in a sharp decline in water quality. Many cities in developing countries are facing problems like higher content of nutrient and organic material in potable water due to untreated domestic and industrial waste into the resources.

The objective of the current study is to assess and analyze groundwater quality of twelve wells at different depths and locations of district Rajanpur used for drinking purposes.

\section{Material \& Method}

The study was carried out at Rajanpur Tehsil which is an administrative subdivision of Rajanpur district. The capital of the Tehsil is Rajanpur City. The Tehsil is administratively subdivided into 16 Union Councils, having a gross area of $2078 \mathrm{sq}$. km. It is situated on river Indus's right bank on Indus Highway. The coordinates of the Tehsil's Capital are $29^{\circ}-05^{\prime}-56$ " N and 70-19'-25" E. Its distance from Dera Ghazi Khan is $112.5 \mathrm{~km}$. The climate of Rajanpur is dry with low rainfall in the whole district. Water samples collected from twelve sites identified by the GPS coordinates are shown in Figure 1.

The samples of groundwater were collected from twelve different locations of eleven union councils, Tehsil Rajanpur and district Rajanpur. The samples were collected from the wells at different depths, mostly near the canals or expected sweet groundwater zones. The sterilized plastic bottles were washed with distilled water twice before the collection of the samples according to the standard methods [7][8]. The water quality parameters were analyzed according to the procedures and the standard methods are summarized in Table 1. The samples collected from the selected locations of Rajanpur, as shown in Table 2, were analyzed in the environmental laboratory of Energy \& Environment Engineering department QUEST Nawabshah.

\section{Results \& Discussion}

The physical, chemical and biological parameters of water samples collected from the selected sites were

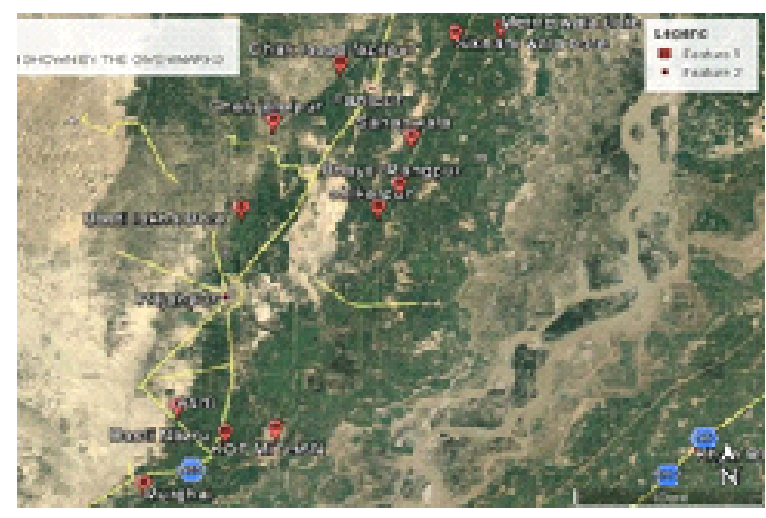

Fig. 1: Locations for groundwater sampling

\begin{tabular}{|c|c|c|}
\hline No. & Parameters of water & $\begin{array}{l}\text { Analysis Method / } \\
\text { Equipment }\end{array}$ \\
\hline 1 & $\begin{array}{l}\text { Total dissolved } \\
\text { salts (TDS) }\end{array}$ & $\begin{array}{l}\text { St. method, } \\
2540 \mathrm{C}(1992)\end{array}$ \\
\hline 2 & $\begin{array}{l}\text { Conductivity } \\
(\mu S / \mathrm{cm})\end{array}$ & $\begin{array}{l}\text { Syber Scan } \\
\text { CON } 11 \text { EC. meter }\end{array}$ \\
\hline 3 & $\mathrm{PH}$ & $\begin{array}{l}\text { pH meter, Jenco, } \\
6230 \mathrm{~N}\end{array}$ \\
\hline 4 & Color & Sensory Test (TCU) \\
\hline 5 & Taste & Sensory Test \\
\hline 6 & Bicarbonate(mg/l) & $\begin{array}{l}\text { St. method, } \\
2320(1992)\end{array}$ \\
\hline 7 & Chloride(mg/l) & $\begin{array}{l}\text { St. method, } \\
\text { Titration (1992) }\end{array}$ \\
\hline 8 & Sulfate & $\begin{array}{l}\text { Spectrophotometer } \\
\text { Opt } 2120 U V\end{array}$ \\
\hline 9 & Hardness (mg/l) & $\begin{array}{l}\text { EDTA Titration } \\
\text { St method } 1992\end{array}$ \\
\hline 10 & Calcium (mg/l) & $\begin{array}{l}\text { 3500-Ca-D, } \\
\text { St. method (1992) }\end{array}$ \\
\hline 11 & Magnesium (mg/l) & $\begin{array}{l}\text { 234-C, Standard } \\
\text { method (1992) }\end{array}$ \\
\hline 12 & Sodium (mg/l) & $\begin{array}{l}\text { Flame photometer } \\
\text { Italy }\end{array}$ \\
\hline 13 & Potassium & Flame photometer \\
\hline 14 & Alkalinity & $\begin{array}{l}2320, \text { Standard } \\
\text { method (1992) }\end{array}$ \\
\hline 15 & Turbidity & $\begin{array}{l}\text { Turbidity meter } \\
\text { Lovibond PC }\end{array}$ \\
\hline 16 & Nitrate & $\begin{array}{l}\text { Colorimeter, } \\
\text { Hach- DR2 } 800\end{array}$ \\
\hline 17 & B.C & $\begin{array}{l}\text { Presence/ } \\
\text { absence test kit }\end{array}$ \\
\hline
\end{tabular}

TABLE 1: Water parameters and methods/equipment used for the analysis 


\begin{tabular}{|l|l|l|l|l|}
\hline No. & Village name & $\begin{array}{l}\text { Sample } \\
\text { ID }\end{array}$ & \multicolumn{2}{|c|}{ GPS Coordinates } \\
\hline 1 & Village Sikhani Wala & S1 & 29.2435 & 70.478 \\
\hline 2 & Village mehre wala & S2 & 29.3359 & 70.565 \\
\hline 3 & $\begin{array}{l}\text { Sehnwal near main } \\
\text { city }\end{array}$ & S3 & 29.2342 & 70.486 \\
\hline 4 & Near Basti Bhayan & S4 & 29.1903 & 70.475 \\
\hline 5 & Village Shikar Pur & S5 & 29.1682 & 70.437 \\
\hline 6 & Kot Mithan city & S6 & 28.9668 & 70.367 \\
\hline 7 & Village Murghai & S7 & 28.9162 & 70.252 \\
\hline 8 & Basti Nazru & S $~$ & 28.9633 & 70.324 \\
\hline 9 & Basti Asni & S9 & 28.9869 & 70.281 \\
\hline 10 & Basti Lakha & S10 & 29.1837 & 70.328 \\
\hline 11 & Jalal Pur/pull pathan & S11 & 29.2494 & 70.364 \\
\hline 12 & $\begin{array}{l}\text { Qutab Pul Haji } \\
\text { pur road }\end{array}$ & S12 & 29.3019 & 70.423 \\
\hline
\end{tabular}

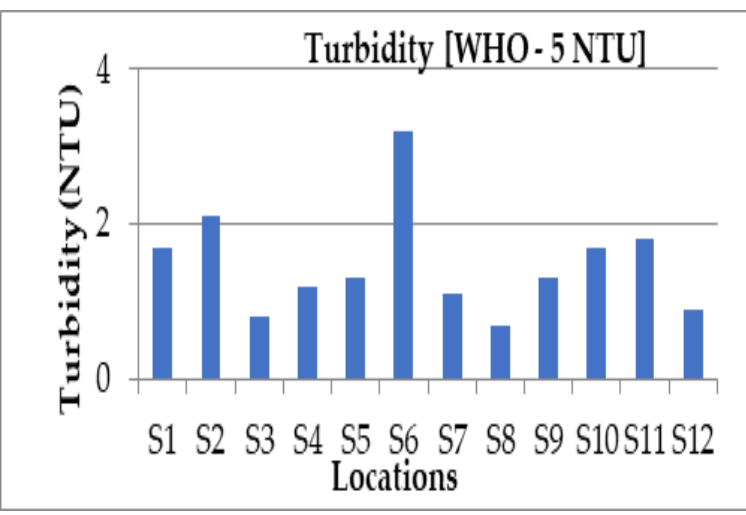

Fig. 2: Turbidity Results

TABLE 2: Sampling Locations

\begin{tabular}{|l|l|l|l|}
\hline No. & Parameters & Sr. No. & Parameters \\
\hline 1 & pH & 9 & Sodium \\
\hline 2 & TDs & 10 & Potassium \\
\hline 3 & Chloride & 11 & Alkalinity \\
\hline 4 & Fluoride & 12 & Nitrate \\
\hline 5 & Sulfate & 13 & Arsenic \\
\hline 6 & Hardness & 14 & Iron \\
\hline 7 & Calcium & 15 & Carbonate \\
\hline 8 & Magnesium & & \\
\hline
\end{tabular}

TABLE 3: Chemical parameters of water

determined in the laboratory to evaluate the suitability of water for drinking purpose by using analysis/equipment as mentioned in Table 1.

\subsection{Physical Parameters}

The physical parameters of groundwater were examined for twenty selected locations. Decaying of organic (vegetation) and inorganic (soil, stones, and rocks) matters impart color to water. Iron becomes yellow or red sediments. All analyzed samples were colorless. Taste and odors were also non-objectionable for all samples.

The presence of suspended particles in water is measured by turbidity level. The turbidity in water is the indication of cloudiness of water and is a key parameter for determining water quality [9]. The obtained results from turbidity analysis, as shown in Figure 2, were found within the permissible limit as recommended by WHO (i.e., 5 NTU) at all locations. Electrical conductivity (EC) is the ionic concentration present in water. Ions in solution cause the flow of electrical current. The results for EC were found between 400 to $1273 \mu \mathrm{S} / \mathrm{cm}$ (Figure 3) with an average value of 892 $\mu \mathrm{S} / \mathrm{cm}$. The results were within the acceptable limit of WHO.

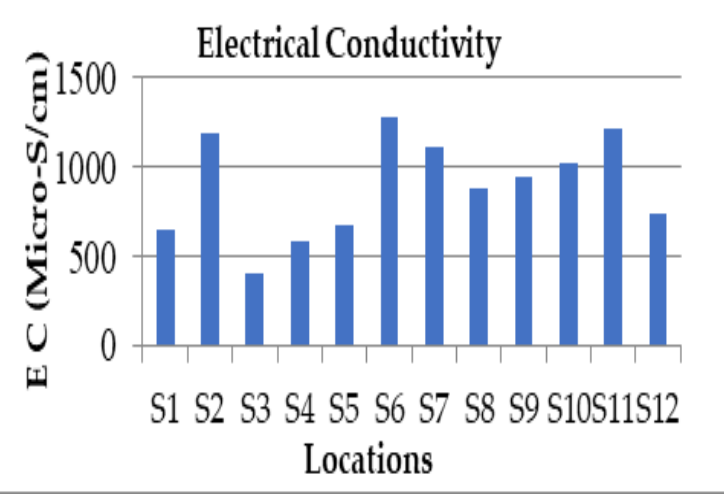

Fig. 3: Electrial Conductivity Results

\subsection{Chemical Parameters}

Various chemical parameters of this study are presented in Table 3. The analysis for all parameters was performed using standard methods The procedures are mentioned in Table 1.

The $\mathrm{pH}$ determines the acidic or alkaline nature of water [10]. The results of $\mathrm{pH}$ found for all locations were in the range 7.42-7.78 (Figure 4) which are within the allowable limit of WHO standard, i.e., 6.5-8.5.

Total Dissolved Solids (TDS) level of $300 \mathrm{mg} / \mathrm{l}$ and less is considered as the best level, the range $300-600 \mathrm{mg} / \mathrm{l}$ is considered as good, $600-1000 \mathrm{mg} / \mathrm{l}$ is considered as fair, and above $1000 \mathrm{mg} / \mathrm{l}$ is higher than the acceptable limit [11]. According to WHO standard, the higher boundary of TDS of potable water is $1000 \mathrm{mg} / \mathrm{l}$. The TDS level was found within the permissible limits at all locations (shown in Figure 5).

Chlorides specify the level of salinity in water. Chlorides in groundwater arises from several sources such as soil weathering, formation of saline lipids and precipitation of salt spray, salt for road melting, and contributions of wastewater. Chloride is not considered as harmful in drinking water, but its concerns are associated with the common relationship with a higher 


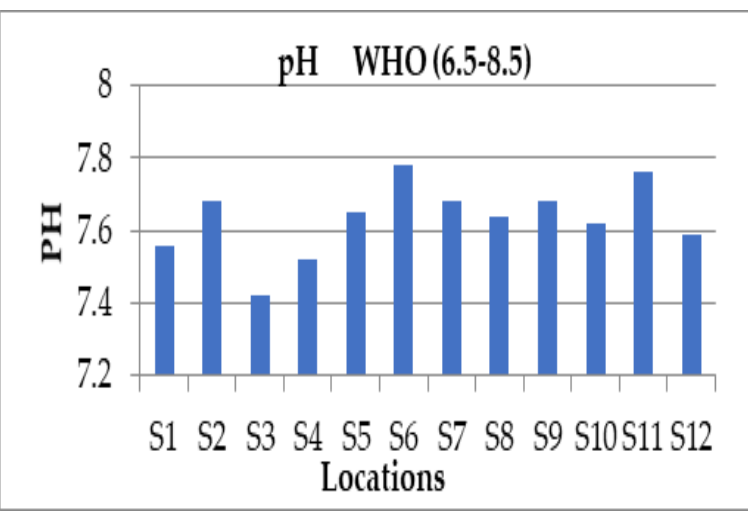

Fig. 4: pH Results

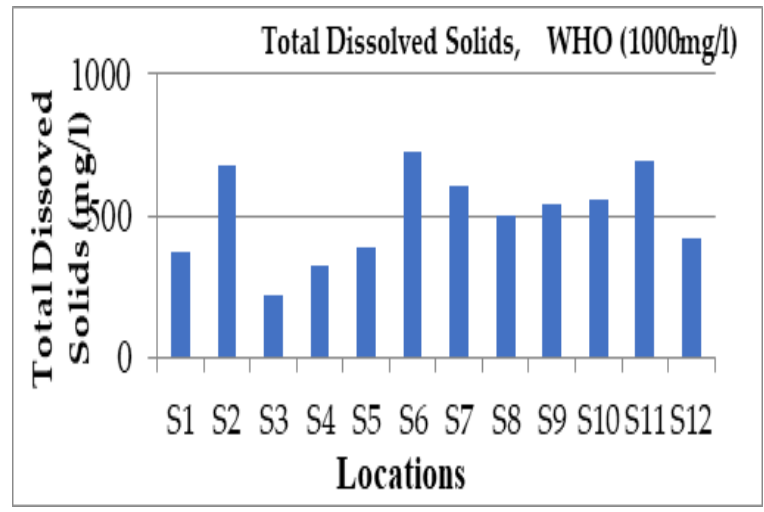

Fig. 5: TDS Results

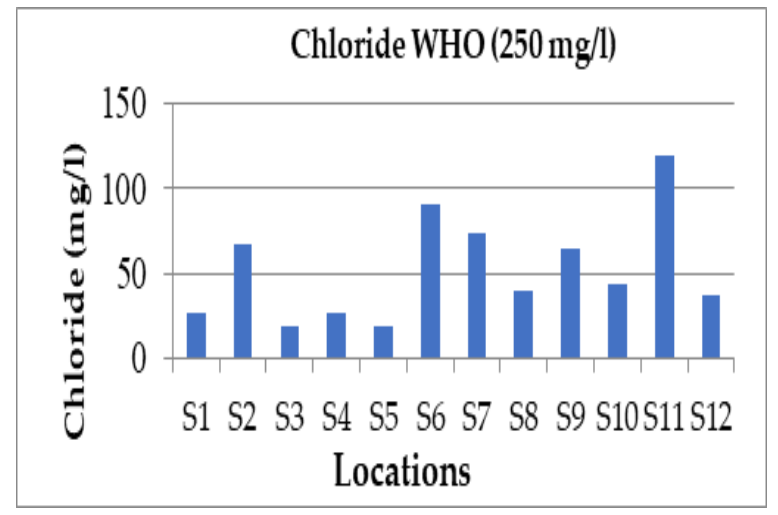

Fig. 6: Chloride Results

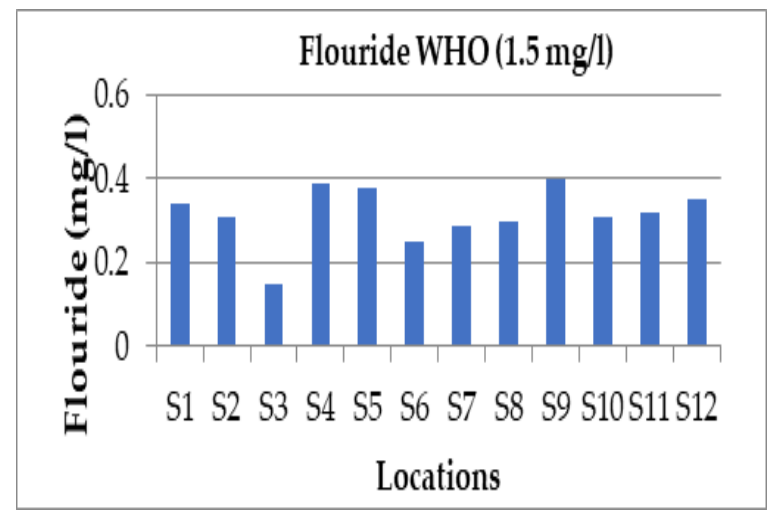

Fig. 7: Floride Results level of sodium. The obtained results for chloride were found within the allowable limit of WHO and NEQS standards, as shown in Figure 6.

The presence of Fluoride in groundwater is due to the weathering and leaching of fluoride bearing minerals from sediments and rocks found in foods such as tea, fish and rice, etc. The WHO recommended the value of fluoride for drinking water as $1.5 \mathrm{mg} / \mathrm{l}$ [12]. The results of fluoride were found between 0.15 $\mathrm{mg} / \mathrm{l}$ to $0.4 \mathrm{mg} / \mathrm{l}$ with an average value of $0.31 \mathrm{mg} / \mathrm{l}$ (Figure 7). The results of all locations for fluoride were found satisfactory. Sulfates in water occurs naturally or from municipal and industrial discharges. A high-level of sulfate in drinking water may result in several health disorders and cause a problem in eye, skin, and scalp irritation, diarrhea, and dehydration. WHO's suggested safe limit for sulfate is $250 \mathrm{mg} / \mathrm{l}$. The results of sulfate concentration, shown in Figure 8, range between $32 \mathrm{mg} / \mathrm{l}-344 \mathrm{mg} / \mathrm{l}$ at different locations. The sulfate level exceeded beyond the acceptable limit at four locations, i.e., at S2, S7, S10 and S11, indicating the potential health threat to human. The hardness test is performed for determining the properties of highly mineralized water. Hardness of water is the sum of calcium ions and magnesium ions, calculated by the analytical method. WHO's suggested hardness upper limit is $500 \mathrm{mg} / \mathrm{l}$ in drinking water. The results of hardness found range from $160 \mathrm{mg} / \mathrm{l}$ to $480 \mathrm{mg} / \mathrm{l}$ (Figure 9). The results of all twelve locations were found within the safe limit as recommended by WHO and NEQS.

Calcium is an essential mineral for bones, cell physiology, and teeth. Surplus calcium intake is very harmful to human health like heart diseases, high blood pressure, irritated skin, diabetes, and reproductive failure [13][14]. The results of this study showed that most of the calcium samples were within the WHO permissible limit of $75 \mathrm{mg} / \mathrm{l}$. However, the analysis found higher calcium amounts than the acceptable limit at these locations, i.e., S7, S8, S9, S10 and S11, as shown in Figure 10.

Magnesium is one of the essential minerals in water for human health. It describes the quality of water for several applications [15]. The safe limit of $\mathrm{Mg}$ suggested by WHO is $150 \mathrm{mg} / \mathrm{l}$ for drinking water. Amount of $\mathrm{Mg}$ was found to be within the permissible limit at all locations (Figure 11).

A high level of $\mathrm{Na}$ changes the taste of water and 


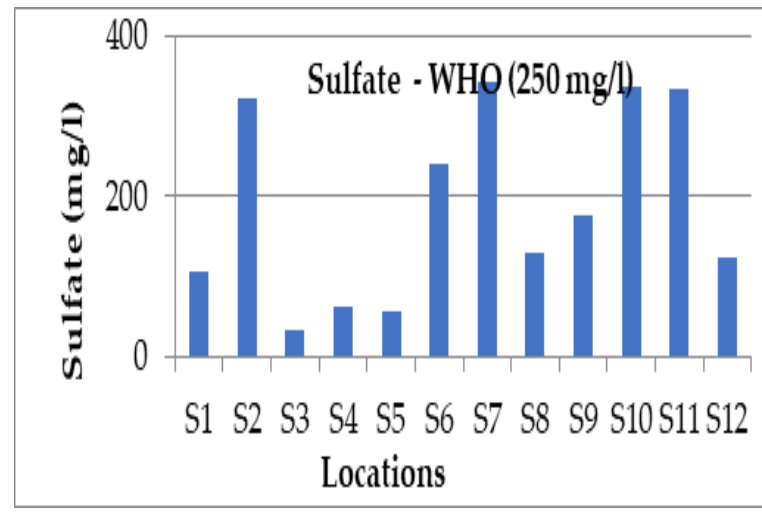

Fig. 8: Sulfate Results

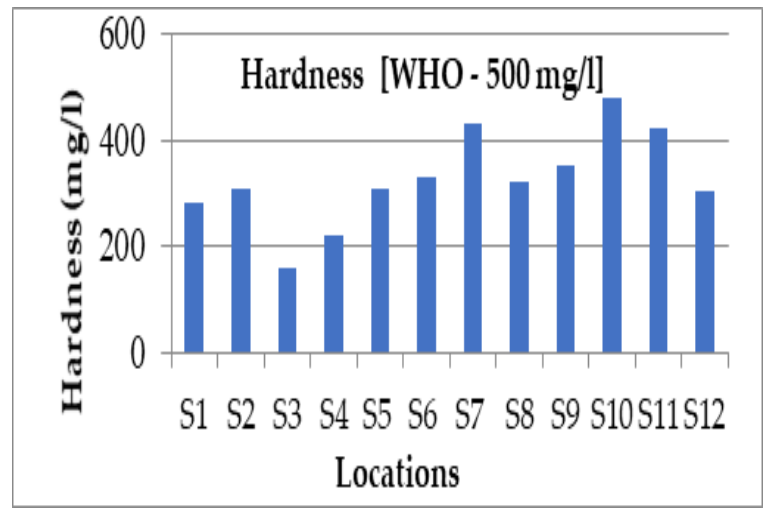

Fig. 9: Hardness Results

can pose potential hazards to human health. Its safe limit suggested by WHO is $200 \mathrm{mg} / \mathrm{l}$ [11]. The results for Na concentration obtained at various locations for all twelve samples were found within the permissible limit (Figure 12). The sodium concentration found at different locations were between $21-183 \mathrm{mg} / \mathrm{l}$.

Potassium $(\mathrm{K})$ is an alkali element and is very helpful for hydration. The European Commission suggests potassium allowable limit for drinking water to be $12 \mathrm{mg} / \mathrm{l}$ [13]. Results of potassium were found within the safe limit ranging from $4.6 \mathrm{mg} / \mathrm{l}-9.8 \mathrm{mg} / \mathrm{l}$ with an average value of $6.5 \mathrm{mg} / \mathrm{l}$, as shown in Figure 13 . The consumption of water with alkalinity higher than permissible level may cause different health issues. The results of alkalinity were found between 3.1-7.1 m.mol/1, as shown in Figure 14, with an average value of $4.9 \mathrm{~m} . \mathrm{mol} / 1$.

Nitrogen is a natural source of nitrate in groundwater. Sources of nitrate are agricultural chemicals, sewage, and industrial effluents. Diseases associated with drinking water having higher nitrate levels are diabetes, thyroid disease, and gastric cancer. WHO recommends the nitrate maximum limit as $10 \mathrm{mg} / \mathrm{l}$ for drinking water. The nitrate results were found

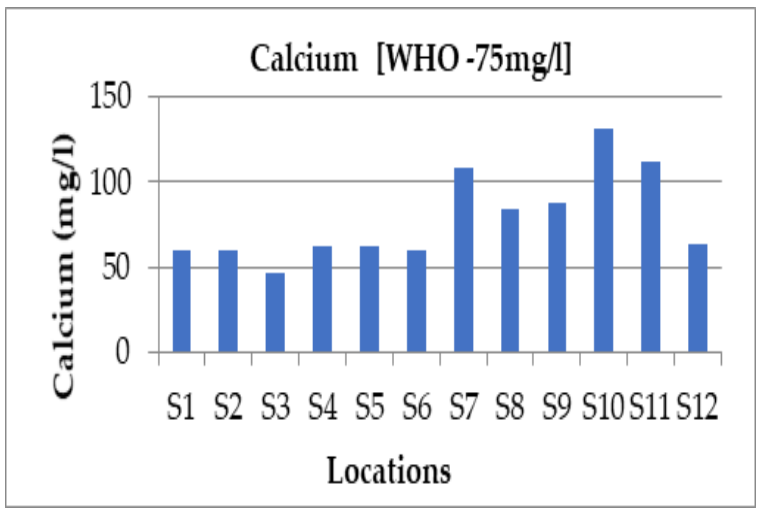

Fig. 10: Calcium Resultss

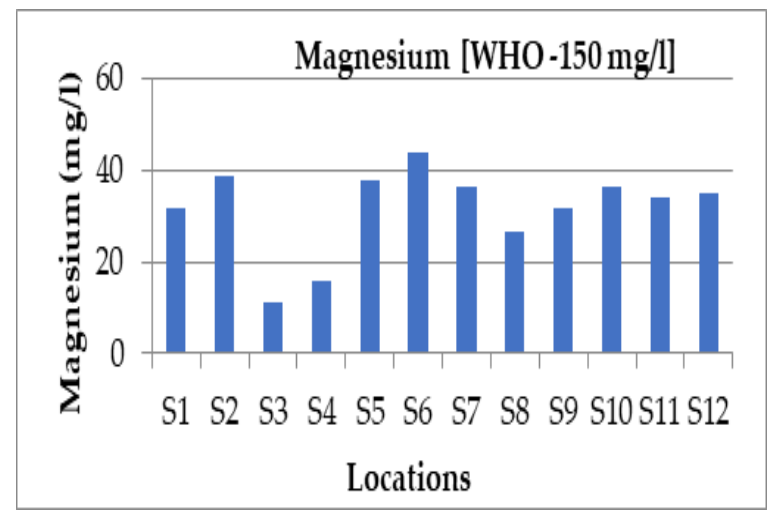

Fig. 11: Magnesium Results

between 0.1 to $1.08 \mathrm{mg} / \mathrm{l}$ within satisfactory limits for all locations (Figure 15).

Arsenic is known as a very toxic and cancer-causing chemical pollutant originate in drinking water. Longterm use of water contaminated with arsenic may cause skin cancer, lungs, bladder, kidney, pigmentation, weakness, numbness, muscular cramping, vomiting, and diarrhea [15]. The permissible limit of arsenic in drinking water suggested by WHO is 10

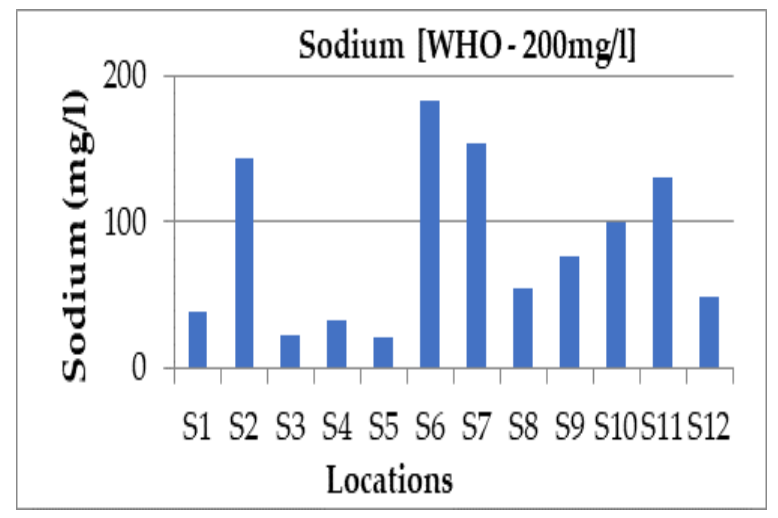

Fig. 12: Sodium Results 


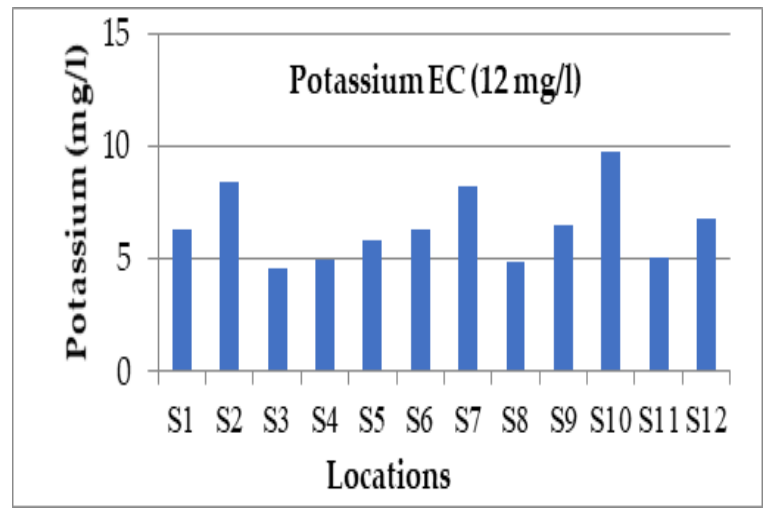

Fig. 13: Potassium Results

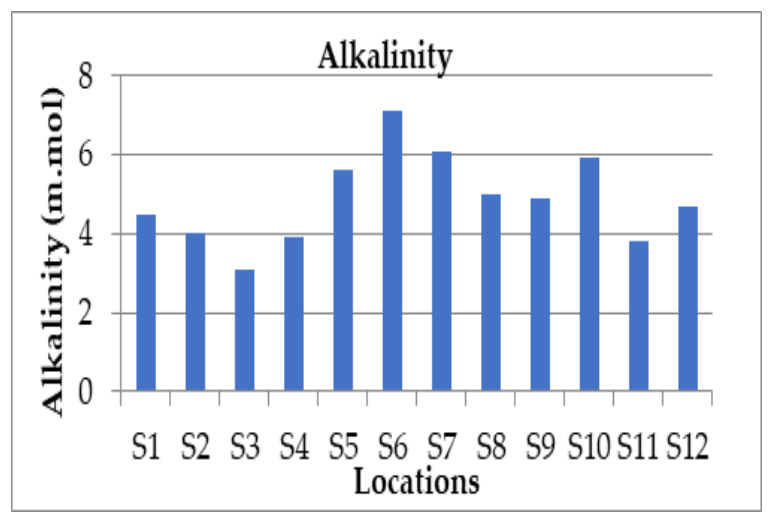

Fig. 14: Alkalinity Results

$\mathrm{g} / \mathrm{l}$. The results obtained for Arsenic range from 10 microgram/liter to 50 microgram/liter. The sample locations S2, S3, S4 were very high and locations S1, S6, S8, S9, S11, S12 were also found beyond the permissible limit. Only three locations S5, S7, S10 showed satisfactory results (Figure 16).

According to the standards suggested by WHO, the concentrations of iron might be less than $0.3 \mathrm{mg} /$ liter in drinking water. Iron concentration may increase due to iron salts used as agents for coagulant. The iron level found in all samples were within the permissible limit as recommended by WHO (Figure 17).

\subsection{Biological Parameters}

Biological parameters are considered as helpful indicators for water quality. Animal and human feces and agricultural activities are the major causes of microbial contamination of water [16]. According to WHO guidelines, potable water should be free from biological contamination, i.e., total coliform and fecal coliform 0/100 $\mathrm{ml}$ [11]. The presence of total coliform in water intake causes waterborne diseases such as gastrointestinal upset, flu, fever, abdominal cramps, and diarrhea. Agricultural runoff, effluent from a septic

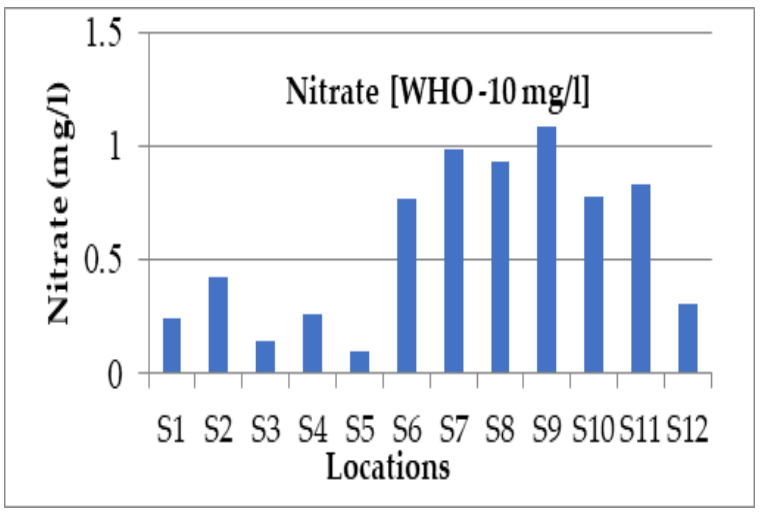

Fig. 15: Nitrate Results

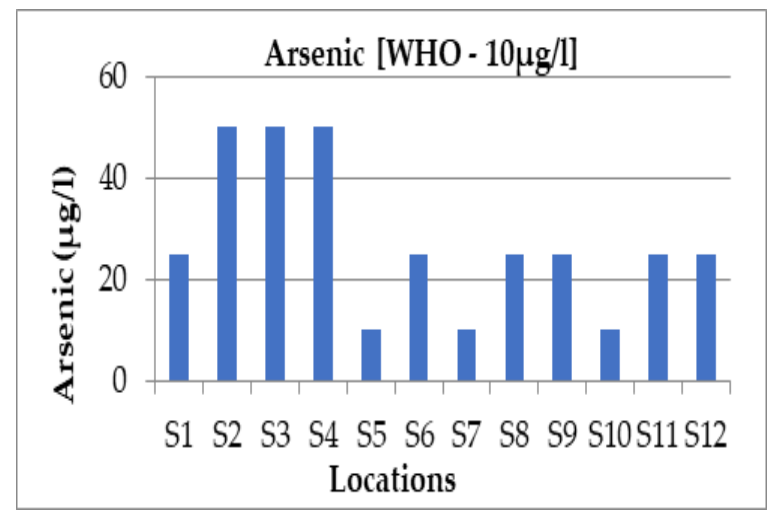

Fig. 16: Arsenic Results

system or sewerage discharge, rainfall, and infiltration of domestic are the main sources of coliform in groundwater [17]. Results showed that the total coliform level exceeded the acceptable limit for samples, i.e., S3, S4, S5 S8 (Figure 18). The results obtained for fecal coliforms were found higher than the acceptable limit [18], particularly in samples S3, S4, S5 S8 (Figure 20).

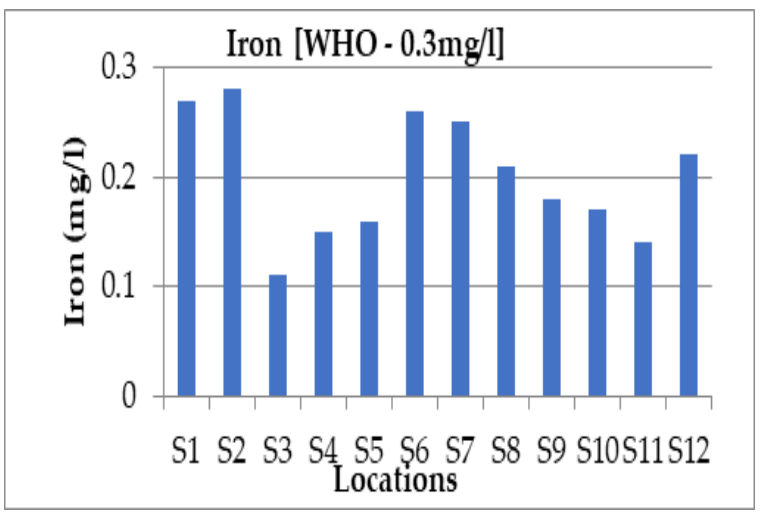

Fig. 17: Iron Results 


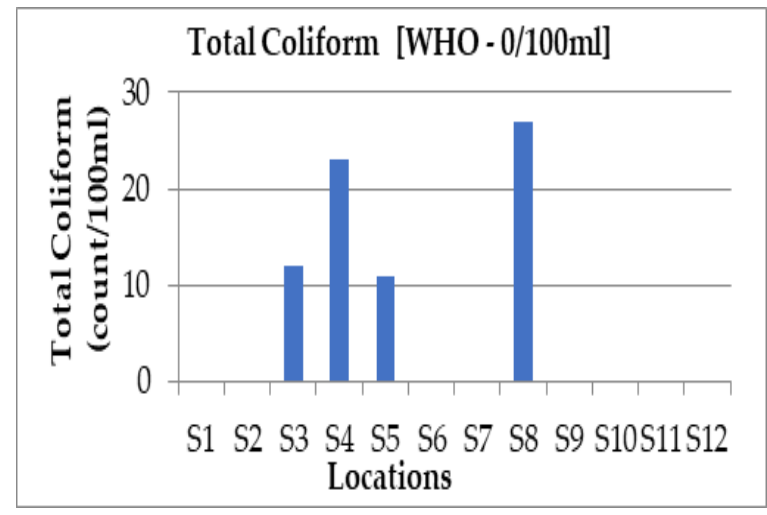

Fig. 18: Total Coliform Results

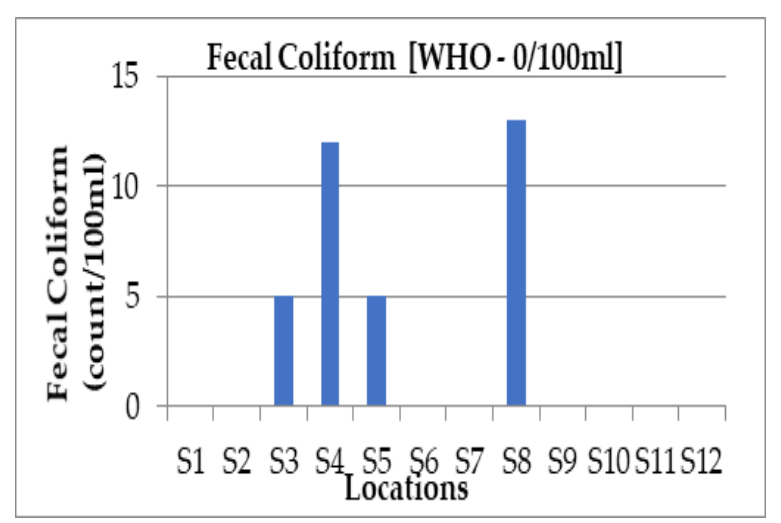

Fig. 19: Fecal Coliform Results

\section{Conclusion}

The present study showed the assessment of various water quality parameters. The observed results revealed that the quality of underground water that is being used by the people of Rajanpur Tehsil was satisfactory at some locations while contaminated at other studied locations. The arsenic, calcium, sulfate, total coliform, and fecal coliform were found beyond the WHO and NEQs standards at twelve locations. The Arsenic limit exceeded at nine locations: S1, S2, S3, S4, S6, S8, S9, S11 and S12. It exposed an alarming situation for those areas. Calcium was above the limit at locations: S7, S8, S9, S10 S11. Also, sulfate was found higher at locations: S2, S7, S10 S11. Total coliform and fecal coliform were found higher at locations: S3, S4, S5 S8. The use of fertilizer and pesticides such as herbicides, insecticides, fungicides, rodenticides, algicides in the agricultural land are the main sources for contamination groundwater. The higher level of calcium and sulfate originated due to the presence of gypsum in the ground. It was observed during the water sample collection that the improper disposal of municipal solid waste was also one of the reasons for groundwater contamination in rural areas of Tehsil
Rajanpur. The effluent from the septic system, sewage discharge, and wild animal fecal underground penetration are the sources of biological contamination. Due to the consumption of contaminated water, the people of Tehsil Rajanpur were facing various health problems. Water treatment is highly recommended before the use of underground water for drinking purpose at the identified contaminated locations.

\section{References}

[1] S. Haydar et. al., "Evaluation of Drinking Water Quality in Urban Areas of Pakistan: A Case Study of Southern Lahore" Pak. J. Engg. \& Appl. Sci. Vol. 5, 2009.

[2] Global Water Partnership, Draft South Asia - Water Vision 2025, Country Report - Pakistan, 2000.

[3] AN Laghari, ZA Siyal, DK Bangwar, MA Soomro, G Walasai, FA Shaikh "Groundwater Quality Analysis for Human Consumption: A Case Study of Sukkur City, Pakistan" Engineering, Technology \& Applied Science Research Vol. 8, No.1, pp.2616-2620, 2018.

[4] S. Khan, M. Shahnaz, N. Jehan, S. Rehman, M. TahirShah, I. Din, "Drinking water quality and human health risk in Char-sadda district, Pakistan", Journal of cleaner production, Vol. 60, pp. 93-101, 2013

[5] Government of Pakistan (GoP). Pakistan Millennium Development Goals Report 2006. Planning Commission, Centre for Research on Poverty Reduction and Income Distribution, Islamabad. Available at http://www.undp.org.pk/images/ publications/MDG\%202006.pdf

[6] Ikem A, Odueyungbo S, Egiebor NO, Nyavor K, "Chemical quality of bottled waters from three cities in eastern Alabama." The Sci Total Environ. vol. 285, pp. 165-175, 2002.

[7] United States Environmental Protection Agency, Quick Guide To Drinking Water Sample Collection, available at https:// www.epa.gov/region8-waterops/guide-drinkingwater-sample-collection.

[8] WHO, Guidelines for Drinking-Water Quality, WHO, 2011.

[9] M. A. Khattak, N. Ahmed, M. A. Qazi, A. Izhar, S. Ilyas, M. N. Chaudhary, M. S. A. Khan, N. Iqbal, T. Waheed, "Evaluation of ground water quality for irrigation and drinking pur-poses of the areas adjacent to Hudiara Industrial Drain, La-hore, Pakistan", Pakistan Journal of Agricultural Sciences, Vol. 49, No. 4, pp. 549-556, 2012.

[10] Nollet LML "Handbook of Water Analysis" Marcel Dekker, New York, USA, pp.87-99, 2000.

[11] World Health Organization "Guidelines for Drinking Water Quality, Surveillance and Control of Community Supplies" Vol. 3, 1997.

[12] R. Buamah, C. A. Oduro, M. H. Sadik,"Fluoride removal from drinking water using regenerated aluminum oxide coated media", Journal of Environmental Chemical Engineer-ing, Vol. 4, No. 1, pp. 250-258, 2016.

[13] Orzepkowski W., Pulikowski K, "Magnesium, calcium, potassium and sodium content in groundwater and surface water in arable lands in the commune gmina of Katy Wroclawskie", Journal of Elementology, Vol. 13, No. 4, pp. 605$614,2008$.

[14] World Health Organization, Calcium and magnesiumin drinking-water, available at: http://www.who.int/water sanitation_health/publications/publication_9789241563550/en/. 
[15] A. Rasool, A. Farooqi, T. Xiao, S. Masood, M. A.Kamran, S. Bibi, "Elevated levels of arsenic and trace metals in drinking water of Tehsil Mailsi, Punjab, Pakistan", Journal of Geo-chemical Exploration, Vol.169, pp. 89-99, 2016.

[16] Cabral J. P. S. "Water Microbiology. Bacterial Pathogens and Water", International Journal of Environmental Research and Public Health, Vol.7, No. 10, pp. 3657-3703, 2010.

[17] AN Laghari, ZA Siyal, MA Soomro, DK Bangwar, AJ Khokhar, HL Soni "Quality Analysis of Urea Plant Wastewater and its Impact on Surface Water Bodies" Engineering, Technology \& Applied Science Research Vol. 8, No. 2, pp.26992703, 2018.

[18] Pakistan Environmental Protection Agency, National Standards for Drinking Water Quality, 2008. 